\title{
Avaliação da Qualidade de Vegetais Minimamente Processados no Estabelecimento Comercial Para Vendas A Granel
}

Thaís Campos Alves (I), Gabriella Araujo Rebouças Oliveira (I), Thaís Souza Silveira (I), Leonardo Emanuel de Oliveira Costa (I), Janaína dos Santos Nascimento (I), Barbara Cristina Euzebio Pereira Dias de Oliveira (I,II)

(I) IFRJ - Instituto Federal de Educação do Rio de Janeiro (Rua Senador Furtado, 121, Maracanã. Rio de Janeiro/RJ, Brasil. CEP: 20270-021), (II) IOC/Fiocruz - Instituto Oswaldo Cruz/Fiocruz (Av Brasil 4365, Pav Gomes de Faria - Manguinhos - Rio de Janeiro - 21040-360)

\section{Resumo}

Práticas inadequadas durante a manipulação ou o processamento do alimento podem facilitar a contaminação, a sobrevivência e a multiplicação de micro-organismos causadores de doenças transmitidas por alimentos. $\mathrm{O}$ comércio varejista por vezes manipula grandes quantidades de alimentos e os supermercados, em especial, o fazem atendendo a uma expressiva parcela da população. Neste ambiente, os produtos podem ser submetidos ao risco de manipulação inadequada e contaminação cruzada da mesma ordem daquele do ambiente industrial. Assim, este projeto visa realizar a análise microbiológica de vegetais minimamente processados no estabelecimento comercial, segundo os padrões microbiológicos estabelecidos na RDC n ${ }^{\circ}$. 12/2001. Foram compradas, durante o horário comercial, amostras de $50 \mathrm{~g}$ de diferentes vegetais minimamente processados em estabelecimentos na Zona Norte da cidade do Rio de Janeiro. Nestas amostras, foram analisados coliformes totais e termotolerantes quantificados pelas técnicas de número mais provável; quantificadas de bactérias mesófilas pelo método de "pour plate" em ágar PCA e, a quantificados de bolores e leveduras, e estafilococos coagulase (+), pelo método “spread plate” em Ágar PDA e Baird-Parker,

\footnotetext{
Referência:

Thaís Campos Alves, Gabriella Araujo Rebouças Oliveira, Thaís Souza Silveira, Leonardo Emanuel de Oliveira Costa, Janaína dos Santos Nascimento, Barbara Cristina Euzebio Pereira Dias de Oliveira. Avaliação da Qualidade de Vegetais Minimamente Processados no Estabelecimento Comercial Para Vendas A Granel. In: Anais do 12o Congresso Latinoamericano de Microbiologia e Higiene de Alimentos - MICROAL 2014 [= Blucher Food Science Proceedings, num.1, vol.1]. São Paulo: Editora Blucher, 2014. DOI 10.5151/foodsci-microal-175
} 
respectivamente. Para a análise de Salmonella spp. foi feito o préenriquecimento em água peptonada $1 \%$ seguido do enriquecimento seletivo nos caldos RV, SC e TT, com posterior isolamento nos ágares XLD, Rambach e Bismuto Sulfito. Para as colônias típicas foram realizados testes bioquímicos, segundo a IN 62. Até o momento foram obtidas nove amostras de vegetais minimamente processados, adquiridas em três estabelecimentos comerciais diferentes, nas quais foram isoladas duas colônias de Salmonella confirmadas pelo teste de soro-aglutinação. Em quatro amostras foi observada uma quantidade de coliformes termotolerantes acima do permitido pela legislação vigente. Para bactérias mesófilas e bolores e leveduras foram encontrados, em sua maioria, amostras com valores entre $10^{4}-10^{5} \mathrm{UFC} / \mathrm{g}$ de amostra. Estas cinco amostras estavam impróprias para o consumo humano representando um risco para o consumidor. Desta forma, nossos resultados demonstram que a área de manipulação de alimentos no comércio varejista constitui um ambiente de extrema importância, embora pouco estudado, visto que ele introduz um novo ponto crítico de controle do processo de produção.

Palavras-Chave: comércio varejista, qualidade microbiológica, Salmonella, vegetais minimamente processados

Agência de Fomento: IFRJ, Faperj e CNPq 